\title{
Canine bone sporotrichosis: a case report
}

\author{
Esporotricose óssea canina: relato de caso
}

\author{
Marconi Rodrigues de Farias $^{1 *}$; Dévaki Liege de Assunçãoº ; Greicy Duarte²; \\ Graziele Vandresen²; Juliana Werner ${ }^{3}$; Ubirajara Tasqueti ${ }^{4}$
}

\begin{abstract}
Sporotrichosis, a subcutaneous and zoonotic mycosis, is caused by dimorphic fungus Sporothrix schenckii. The infection occurs after a traumatic skin injury, while handling plant materials or animals. This disease commonly occurs in cats and is rarely reported in dogs. Herein we report a case of bone sporotrichosis in a dog that presented at the Hospital Unit for Pets (HUP) of the Pontifical Catholic University of Paraná (PUCPR). The animal had a 4-month history of lameness in its thoracic limbs. Haematological, radiological, mycological, and histopathological tests were conducted to confirm the diagnosis. The animal was treated for 2 months with a $10 \mathrm{mg} \mathrm{kg}^{-1}$ PO SID dose of itraconazole, but only partial improvement was observed. A $20 \%$ supersaturated potassium iodide solution i.e., a $40 \mathrm{mg} \mathrm{kg}^{-1}$ dose every $24 \mathrm{~h}$ was then included for regression and healing of the wounds.
\end{abstract}

Key words: Sporothrix schenckii, zoonosis, dog

\section{Resumo}

A esporotricose é uma micose subcutânea e zoonótica, causada pelo fungo dimórfico Sporothrix schenckii. A infecção ocorre através de uma lesão traumática na pele associada ao meio ambiente ou animais. É uma doença incomum em cães, e está mais frequentemente associada aos felinos. Este artigo relata o caso de um canino atendido na Unidade Hospitalar de Animais de Companhia (UHAC) da Pontifícia Universidade Católica do Paraná (PUCPR) com diagnóstico de esporotricose óssea. O animal apresentava como sinal clínico claudicação em membros torácicos há quatro meses. Para confirmação do diagnóstico foram realizados exames hematológico, radiológico, micológico e histopatológico. $\mathrm{O}$ animal foi tratado durante dois meses com itraconazol na dose de $10 \mathrm{mg} \mathrm{kg}^{-1} \mathrm{SID}$, por via oral com melhora parcial, foi associado ao protocolo uma solução hipersaturada de iodeto de potássio a $20 \%$, na dose de $40 \mathrm{mg} \mathrm{kg}^{-1}$, a cada 24 horas, obtendo-se regressão e cura das lesões.

Palavras-chave: Sporothrix schenckii; zoonose; cão

\footnotetext{
1 Prof. Adjunto III de Clínica Médica de Animais de Companhia, Pontifícia Universidade Católica do Paraná, PUCPR, Curitiba, PR, Brasil. E-mail: marconi.puc@terra.com.br

2 Discentes do Programa de Pós-Graduação em Ciência Animal, PUCPR, Curitiba, PR, Brasil. E-mail: devaki.la@hotmail.com; greicy.duarte@outlook.com; grazivan@gmail.com

3 Médica Veterinária, Werner \& Werner-Laboratório de Patologia Veterinária, Curitiba, PR, Brasil. E-mail: juliana@werner.vet.br

4 Prof. Adjunto de Diagnóstico por Imagem Veterinária, PUCPR, Curitiba, PR, Brasil. E-mail: ubirajara.tasqueti@pucpr.br

* Author for correspondence
} 


\section{Introduction}

Sporotrichosis was first reported by Benjamin Schenck in 1896, and subsequently the pathogenic fungus Sporothrix schenckii was identified by Hekton and Perkins in 1900. S. schenckii is a saprophytic, environmental, and cosmopolitan fungus commonly found in soil, straw, wheat grains, fruits, bark, wood, shrubs, mosses, and decaying vegetation (BARROS et al., 2010; LARSSON, 2011). The fungus is in the mycelial form at temperatures between $25-30^{\circ} \mathrm{C}$. In the parasitic form, it acts as yeast at $37^{\circ} \mathrm{C}$ and is capable of causing tissue, bone, and visceral infections (BEZERRA et al., 2006).

Sporotrichosis has been described in several animal species including dogs, cats, horses, cattle, goats, camels, pigs, chickens, rats, mice, chimpanzees, and humans (SCHUBACH et al., 2006). It causes mycosis of implantation, and infection occurs by traumatic implantation through the skin or by contamination of wounds; however, inhalation, aspiration, or ingestion of the fungus can also cause the disease (BRUM et al., 2007).

In humans, sporotrichosis can be considered an occupational dermatosis and a largely prevalent in gardeners, fruit and vegetable cultivators, and farmers. In addition, the morbidity may also be caused by zoonotic infections in individuals, with or without a history of traumatic accidents, who are in direct contact with the secretions of sick cats; this makes animal care providers and veterinary doctors predisposed to the disease (LARSSON, 2011).

Clinically, sporotrichosis presents in 3 forms: localized or fixed cutaneous form, lymphocutaneous form, and disseminated or systemic form (BARROS et al., 2010; LARSSON, 2011). The localized form is characterized by firm, whole, or ulcerated nodules that develop at the fungal inoculation site. This usually represents a host immune response stage and can be associated with spontaneous involution. The lymphocutaneous form involves the skin, adjacent subcutaneous, and lymphatic tissues and is commonly associated with regional lymphadenitis.
This is the most common form observed in humans. The disseminated or systematic form usually occurs as a rare sequel of the lymphocutaneous form. In these cases, the liver and lungs are the main sites of dissemination; however, the spleen, kidney, testis, eyes, bones, central nervous system, gastrointestinal tract, and mammary glands may also be affected (CROTHERS et al., 2009).

Cats are normally infected with sporotrichosis and often develop a scattered cutaneous condition. The systemic form of the disease has been more observed in this species and may present a disseminated respiratory or systemic condition, often associated with cachexia (NOBRE et al., 2001). In dogs, sporotrichosis is considered unusual, and the ratio of dogs to cats is 1:25 (LARSSON, 2011; SCHUBACH et al., 2008), both in São Paulo and Rio de Janeiro.

In dogs, sporotrichosis occurs primarily in the fixed cutaneous or disseminated cutaneous form, which is characterized by firm, multiple nodules, or by gummy ulcerations, mainly in the body, head, and ears (MADRID et al., 2007).

This study aims to report a case of bone sporotrichosis in a dog and emphasizes on the clinical, diagnostic, and therapeutic aspects.

\section{Case Report}

A 3-year-old male dog, non-neutered outdoor Boxer, was treated at the Hospital Unit for Pets (HUP) of the PUCPR with a history of chronic lameness in its right hind and left front limbs. Previous treatment with corticosteroids, carprofen, and metronidazole did not show any clinical improvement.

Clinical examination showed lameness in the front limb associated with joint effusion on the left wrist. In addition, popliteal lymphadenomegaly and right tibial-tarsal joint pain were also observed.

Radiographic evaluation of the affected thoracic and pelvic limbs revealed irregular periosteal 
proliferation in the cranio-medial surface of the left radius, with osteolysis points (Figure 1) and areas of periosteal proliferation on the caudal medial surface of the distal portion of the tibia and in the right calcaneus bone.
The abdominal ultrasonographic evaluation and urinalysis results were normal, and the blood count revealed leukocytosis with mature neutrophilia.

Figure 1. Image showing irregular periosteal proliferation in the cranio-medial aspect of the left radius, with circular osteolytic areas, secondary to bone sporotrichosis, in a 3-year-old dog, a Boxer.

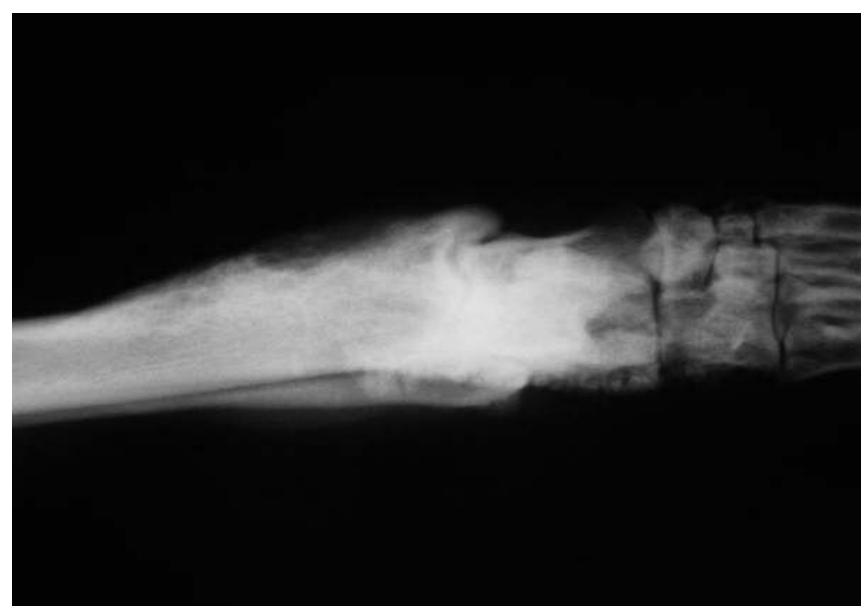

Bone and lymph node biopsies were performed and carpal, radial, and popliteal lymph node fragments were collected and subsequently sent for histopathological analysis and for bacterial and fungal cultures. A histopathological evaluation was performed using the popliteal lymph node, which revealed partially obliterated tissue architecture from an intensive multifocal and coalescent inflammatory infiltration, composed mainly of neutrophils and macrophages. Areas of coagulation necrosis with fibrin deposition were also observed. The results of a special fungal staining technique (PAS c/d) were positive and revealed rare, round, ovoid fungal structures of approximately $8 \mu \mathrm{m}$ in diameter among the inflammatory cells (Figure 2).

The fungal culture on Sabouraud agar, incubated at $25-30^{\circ} \mathrm{C}$, demonstrated the growth of a mycelial colony, with a thin wrinkled surface, adherent to the culture medium, resistant, and sometimes forming an aerial mycelium. Initially, the colour of the colony was cream, but darkened on maturity, eventually becoming dark brown and almost black.

Microscopic observation revealed thin and septate hyphae, with small ovoid conidia at the end of a miniature sterigmata over a conidiophore, in a pattern resembling daisy petals, which led to the diagnosis of osteomyelitis caused by Sporothrix schenckii (bone sporotrichosis).

The results of the fungal culture prompted oral treatment with itraconazole at a dose of $10 \mathrm{mg} \mathrm{kg}^{-1}$, every $24 \mathrm{~h}$, as well as meloxicam $0.1 \mathrm{mg} \mathrm{kg}^{-1}$ every $24 \mathrm{~h}$ for 7 days and tramadol hydrochloride $2 \mathrm{mg}$ $\mathrm{kg}^{-1}$, every $8 \mathrm{~h}$, for 10 days.

After 30 days of treatment with itraconazole, the clinical condition of the animal showed partial improvement. Therefore, $20 \%$ supersaturated potassium iodide solution at a dose of $40 \mathrm{mg} \mathrm{kg}^{-1}$, every $24 \mathrm{~h}$, was included in the treatment. 
Figure 2. Histopathological analysis of the popliteal lymph node that shows ovoid fungal structures of approximately $8 \mu \mathrm{m}$ in diameter, among inflammatory cells and macrophages. PAS positive staining (c/d).

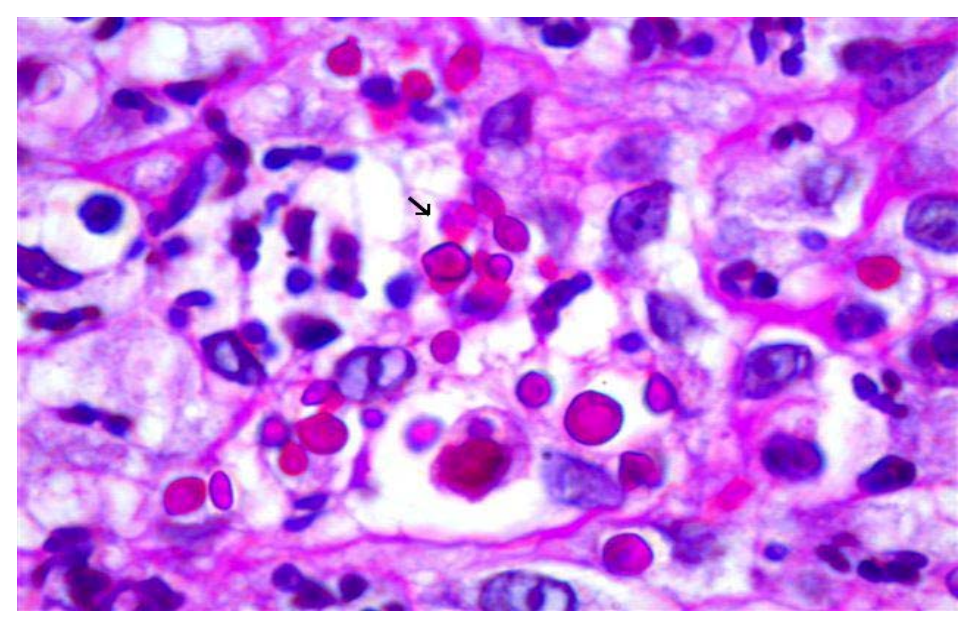

After 60 days of this associated therapy, significant improvement in the clinical status was observed, and the dog no longer showed arthralgia, joint effusion, and lameness. Radiographic evaluation showed that the areas of periosteal proliferation in the radius presented without inconsistencies and osteolysis was not observed.

Treatment was continued for an additional two months, without recurrence of morbidity and changes in clinical and laboratory parameters.

\section{Discussion}

Sporotrichosis infection can occur sporadically by alternative routes; lethal forms of extracutaneous sporotrichosis have been demonstrated in cats, occurring in the lungs, kidneys, testis, joints, and bones. Sporotrichosis is rarely reported in dogs and is usually associated with immunosuppression due to infectious disorders, systemic diseases, cancer, or iatrogenic disorders because of excessive use of steroid therapy (LARSSON, 2011).

The most commonly observed clinical presentation in dogs is disseminated cutaneous or cutaneous lymphatic sporotrichosis (BARROS et al., 2010; LARSSON, 2011). In this case study, the dog presented with bone infection without apparent skin involvement. In many reported cases of canine sporotrichosis, the disease is acquired during hunting activities with possible infection due to thorn piercing or wood chips (SCHUBACH; SCHUBACH, 2000). Epidemiological and socioenvironmental data analysis after a survey by Barros et al. (2010), showed that, in homes with animals and people infected with sporotrichosis, $83.5 \%$ had several plants, $59.9 \%$ had soil, and $43.8 \%$ had construction materials and scrap in their backyards, which are environments that favour S. schenckii proliferation. The dog in the present case used to live in the backyard, and therefore, the environment was the most likely source of infection. The infection was caused due to inoculation of fungal elements near the radiocarpal region, and bone involvement occurred due to contiguity. Another hypothesis is that the animal had a fixed cutaneous or lymphocutaneous infection, which spread to the bone via the lymphatic or haematogenous route.

Larsson (2011) reports that sporadic sporotrichosis infection can occur through alternative routes, such as the respiratory or digestive routes, with subsequent development of systemic disease, which may also have occurred in this dog.

In Rio de Janeiro, between 1998 and 2004, 2,326 affected patients were registered (759 
humans, 64 canines, and 1503 felines); out of these, $85 \%$ of dogs and $83.4 \%$ cats had contact with cats infected with sporotrichosis, while 55.8\% of the human patients reported scratches and/or bites by felines (LARSSON, 2011); however, in immunocompromised patients, due to alcoholism, diabetes, chronic obstructive pulmonary disease, transplantation, corticosteroid therapy, and AIDS virus infection, there is an increased likelihood of disseminated fungal infections (CARVALHO et al., 2002). The animal in this report had no underlying immunosuppression.

Laboratory and imaging testes associated with a detailed history ruled out any possible causes of immunocompromisation; therefore, we hypothesize that bone sporotrichosis has a natural evolution, as well as in immunocompetent felines, who tested negative for Viral Feline Leukemia (VFeL) and for feline immunodeficiency virus (FIV) and still developed sporotrichosis.

According to literature, radiographic changes in bone sporotrichosis occur late and is normally observed in chronic cases with no specific characteristics (MADRID et al., 2007), similar to that observed in the present case. Therefore, it is necessary to perform invasive procedures, such as bone biopsy, for the diagnosis of fungal osteomyelitis. Apart from physical examination, sporotrichosis is diagnosed based on various tests, such as cytodiagnosis, mycological culture, histopathology, serology, intradermal tests, and polymerase chain reaction tests (PCR) that confirm the presence of an infectious agent (LARSSON, 2011).

After 30 days of treatment with itraconazole, a partial improvement in the clinical status was observed, and therefore, potassium iodide was included in the therapeutic protocol with satisfactory results. Potassium iodide was considered the drug of choice for treatment of sporotrichosis for many years, and it still is used for the treatment of cutaneous and lymphocutaneous forms of the disease in humans (MAHAJAN et al., 2005).
The mechanism of action of potassium iodide is still unknown. It does not act in vitro against Sporothrix schenckii, and its action in vivo seems to be related to phagocytosis stimulation by modulating the inflammatory response and increasing neutrophil fungicidal potential (LARSSON, 2011).

Felines are very sensitive to iodide preparations and should be closely monitored for evidence of iodism such as fever, ptyalism, anorexia, hyperexcitability, dry coat, vomiting, or diarrhoea. In dogs, these side effects are rare, and the recommended dosage is $0.4 \mathrm{~mL} \mathrm{~kg}^{-1}$, administered orally every 8 h (LARSSON, 2011).

\section{Conclusion}

Bone involvement is a rare clinical manifestation of sporotrichosis in dogs. In the present case, inoculation during trauma may have been the source of infection, which by contiguity, may have invaded the bone tissue due to haematogenous or lymphatic dissemination. Due to diagnostic difficulty, fungal osteomyelitis cannot be diagnosed early, and bone biopsy and fungal culture are required. Treatment with imidazoles associated with saturated $20 \%$ solution of potassium iodide is capable of causing lesion-symptom regression, if treatment is maintained for at least two months after clinical cure.

\section{References}

BARROS, M. B. L; SCHUBACH, T. P.; COLL, J. O.; GREMIÃO, I. D.; WANKE, B.; SCHUBACH, A. Esporotricose: a evolução e os desafios e uma epidemia. Revista. Panamericana de Salud Pública, Washington, v. 27, n. 6, p. 455-460, 2010.

BEZERRA, L. M. L.; SCHUBABCH, A.; COSTA, R. O. Sporothrix schenckii and Sporotrichosis. Anais da Academia Brasileira de Ciências, Rio de Janeiro, v. 78, n. 2, p. 293-308, 2006.

BRUM, L. C.; CONCEIÇÃO, L. G.; RIBEIRO, V. M., HADDAD JUNIOR, V. Principais dermatoses zoonóticas de cães e gatos. Clínica Veterinária, São Paulo, v. 7, n. 69, p. 29-46, 2007. 
CARVALHO, M. T. M.; CASTRO, A. P.; BABY, C.; WERNER, B.; FILUS NETO, J.; TELLES, F. Q. Disseminated cutaneous sporotrichosis in a patient with AIDS: report of a case. Revista da Sociedade Brasileira de Medicina Tropical, Uberaba, v. 35, n. 6, p. 655-659, 2002.

CROTHERS, S. L.; WHITE, S. D.; IHRKE, P. J.; AFFOLTER, V. K. Sporotrichosis: a retrospective evaluation of 23 cases seen in northern California (19872007). Veterinary Dermatology, Oxford, v. 20, n. 4, p. 249-259, 2009.

LARSSON, C. E. Esporotricose. Brazilian Journal of Veterinary Research Animal Science, São Paulo, v. 48, n. 3, p. 250-259, 2011.

MADRID, I. M.; XAVIER, M. O.; MATTEI, A. S.; CARAPETO, L. P.; ANTUNES, T. A.; SANTOS JÚNIOR, R.; NOBRE, M. O.; MEIRELES, M. C. A. Esporotricose óssea e cutânea em canino. Brazilian Journal of Veterinary Research Animal Science, São Paulo, v. 44, n. 6, p. 441-443, 2007.

MAHAJAN, V. K.; SHARMA, N. L.; SHARMA, C.; GUPTA, M. L.; GARG, G.; KANGA, A. K. Cutaneous sporotrichosis in Himachal Pradesh, Índia. Mycoses, v. 48 , n. 1, p. 25-31, 2005.
NOBRE, M. O.; CASTRO, A. P.; CAETANO, D.; SOUZA, L. L.; MEIRELES, M. C. A.; FERREIRO, L. Recurrence of sporotrichosis in cats with zoonotic involvement. Revista Iberoamericana de Micologia, v. 18, n. 3, p. 137-140, 2001.

SCHUBACH, A.; BARROS, M. B.; WANKE, B. Epidemic sporotrichosis. Current Opinion in Infectious Diseases, Londres, v. 21, n. 2, p. 129-133, 2008.

SCHUBACH, T. M. P.; SCHUBACH, A. O. Esporotricose em gatos e cães - revisão. Clínica Veterinária, São Paulo, v. 5 , n. 29 , p. $21-24,2000$.

SCHUBACH, T. M. P.; SCHUBACH, A.; OKAMOTO, T.; BARROS, M. B. L.; FIGUEIREDO, F. B.; CUZZI, T.; PEREIRA, S. A.; SANTOS, I. B. dos; PAES, R. A.; LEME, R. P.; WANKE, B. Canine sporotrichosis in Rio de Janeiro, Brazil: clinical presentation, laboratory diagnosis and therapeutic response in 44 cases (19982003). Medical Mycology, Oxford, v. 44, n. 1, p. 87-92, 2006. 